\title{
Puck's Broom and the Ontology of Play
}

\section{ÁGNES MATUSKA \& KAREN KETTNICH}

Abstract: In this paper, we explore the ways Shakespeare's A Midsummer Night's Dream stages its own status as theatrical fiction, then analyse the subtle web of fiction and reality it creates, and the ways it incites the audience to take part in this network. The most intriguing instances of the play's undertaking of relating fiction and fact are the ones which hold out promises of illuminating the transition between the two. After presenting some important instances of such transition, or, in the play's own terminology; "translations," this paper will deal in particular with Puck's closing speeches, with a special focus on a puzzling reference to his broom as well as to his sweeping. By focusing on the potentially diverse functions, and even more importantly, on the rich dramatic heritage of Puck's broom, we will examine what more general things it tells us about the ways theatrical fiction and the audience's reality interact.

"[T]ales-within-tales do not deliver the thing itself.

Instead they please by harnessing the powers of fabrication proper to the signifier."

(Catherine Belsey)

The metaphor equating life and theatre, or life and stage, was a central one in Elizabethan England, and with its proliferation on stage, the meaning of the trope became even more kaleidoscopic than earlier. Lynda Christian gives a detailed description of the diverse Hellenistic uses of the topos, including Stoic and satiric, as well as the medieval decline in its use, preceding its renaissance revival and dramatic rise in uses and interpretations, various and contradictory meanings ranging from the vanity of human life to manifold optimistic understandings. Diverse renderings of the topos certainly characterised Shakespeare's age as well, 


\title{
ÁGNES MATUSKA \& KAREN KETTNICH
}

including Shakespeare's oeuvre itself, even within a single play. The widely known version in As You Like It at the beginning of Jacques' monologue suggests a melancholy understanding of the theatrum mundi compared, for example, to Rosalind's creative and performative use of roleplay - a theatrical enactment of the topos rather than a literal citation. A central reason for the diversity of the use of the theatre metaphor can be found in the fact that a long-established theatrical figure suddenly appears at a new medium, the public theatre, giving way to surprising and new meanings that are difficult to control. The topographically liminal position of theatres outside the city walls reflects their indefinite ideological status. As Stephen Mullaney states, the Elizabethan playhouse was

\begin{abstract}
... dislocating itself from the confines of the existing social order and taking up a place on the margins of society. Erected outside the walls of early modern London in the 'licentious liberties' of the city, the popular playhouses of Elizabethan England occupied a domain that had traditionally been reserved for cultural phenomena that could not be contained within the strict or proper bounds of the community. (vii)
\end{abstract}

The self-representation of theatres explores this rich and controversial ground. The pretence involved in acting that is required to present a dramatic narrative on stage could at most be true in a poetic sense, but it also necessarily harboured the potential of remaining mere illusion, void of any substantial reality or an acceptable raison d'être. ${ }^{1}$ Elizabethan theatre is famous for its boldness in addressing contemporary topical issues, and it certainly did not leave out the discussion of its own status as theatre either; metadramatical references abound in the plays of this era, revealing the anxiety around, or the potential function of, theatrical play. ${ }^{2}$ Plays-withinplays are just one example of metadramatic references, which may function, apart from their embeddedness within the actual dramatical context, as more general illustrations of the function and nature of play within the social context that, in turn, gives to theatrical play a hostile rejection or a friendly embrace. This same question, the function of theatre, becomes the actual concern of the play metaphor in this age: Once the appearance of the play metaphor is associated with a theatrical context,

\footnotetext{
1 The debate between puritan opponents of theatre and fiction in general on the one hand and the supporters on the other reflects the main concerns of this debate, the presentation of which is not our major concern here. For further reading see Barish and Matuska.

2 See, for example, Hornby, Calderwood, and Righter.
} 


\section{PUCK'S BROOM}

its explanatory value shifts from illuminating the meaning of life as vanitas to saying something about the power of theatre.

A central theme, if not the crux of A Midsummer Night's Dream, is specifically about this power: the relationship between imagination, dream, fiction and play on the one hand, and their opposite that is needed to delineate them on the other: reality. While the only reality considered by the traditional understanding of the play metaphor would be God's everlasting one, accessible to humans after exiting their mortal coil, the play metaphor enframed by self-referential play allows for a more suspicious, and also a more flexible understanding of what makes reality real. " "Translation" between the realms of fictions and facts works both ways, as happens several times in the play. It seems that a central interest of the play is not only to explore this relationship and the potential power of fiction but also to confront the audience with differing contemporary ideas about this matter. As Catherine Belsey points out, "fiction gives us unique access to [the uncertainties of everyday life] in that, unlike everyday life, it crystallises incompatible or conflicting attitudes in texts. Culture in all its dissonance is thus made available for inspection" (97). In our analysis of relevant aspects of the play, we would like to suggest what we see to be the conflicting attitudes regarding the ontology of fiction - and specifically theatrical fictionpresented by the text, as well as what seems to be the text's preferred attitude.

The rehearsal and the play of Bottom and his company, and their anxiety over the audience's improper response to their playing, brilliantly summarise the multiple perspectives informing the contemporary meaning of theatrical play. As Jackson I. Cope points out, the way the mechanicals think about the effect of their play reveals "the radically double nature of the dramatic experience" (223). Bottom offers a seemingly naïve solution to the problem of scenes that may seem displeasing and frightening to the female members of their audience (such as the lion or the death of the lovers) by stressing their theatrical, illusionistic aspect:

$$
\text { ... Pyramus }
$$

is not killed indeed; and for the more better assurance, tell them that I, Pyramus, am not Pyramus, but Bottom the weaver. $(3.1 .17-20)^{4}$

3 For a detailed overview of the traditional connection between dream and theatre see Cope, who includes an impressive visual example expressing the relationship between theatre and dream in a drawing by Michelangelo entitled Il Sogno (25).

4 References to Shakespeare's plays are from the Arden Shakespeare Complete Works. 


\section{ÁGNES MATUSKA \& KAREN KETTNICH}

As Cope reveals, Bottom's opinion shares remarkable characteristics with ideas of notable thinkers about the nature of theatre, being both illusionistic and anti-illusionistic at any given moment, ${ }^{5}$ since it involves the presence of the actors at the same time both as their everyday selves and as the characters they impersonate, very much in the manner that Bottom wishes to make clear by suggesting that the lion's skin should cover Snug only to the extent he is visible below. So, the undoubtedly ridiculous efforts of the mechanicals to eliminate the absurd possibility of their audience being unaware of the conventions of dramatic fiction can also be read as stressing the inevitable double quality of actors on stage, lending their physical bodies to act also as media to represent the respective characters they play. Importantly, however, the questionable illusory quality of what is represented through the medium of the body is given a further twist in this play. In case we accept the invitation of $A$ Midsummer Night's Dream to establish a metaphorical relationship between supposedly illusionistic visions seen in dreams on the one hand and stage on the other (most explicit in Puck's epilogue, to be discussed below), we realise that dreams and, consequently, plays in this drama are anything but presented as unreal. Rather, the opposite is true. Such a perspective is revealed by Cope as well when he points out in connection with Bottom's transformation into an ass that his vision, "like all the dreams of A Midsummer Night's Dream, is true both literally, and . . . symbolically" (224).

A counter-argument, allowing no substantial reality to products of imagination's fancy, is presented by the authoritative figure of the duke, Theseus, in his speech about lovers and madmen. Still, although Theseus seems to be ridiculing the lovers" stories as "more strange than true," as fantasies empty of any solid reality, his harsh opinion of fables and the tricks of imagination is undermined not only by the dramatic irony rooted in the audience's awareness of the larger context of what has actually happened in the woods but also by the ambiguities of the speech itself. Somewhat contrary to his contempt towards the whole group of poets, lovers, and madmen, Theseus in the end does present a view of the poet as creator when he describes his pen as something that turns things unknown into "shapes, and gives to airy nothing / A local habitation and a name" (5.1.16-17). This formulation

5 Cope points out that Bottom's opinion in comparable to Ortega y Gasset's observation on the "dual being" of an actress and her playing Ophelia: "the stage and the actor are the universal metaphor incarnate, and this is the theater: visible metaphor" $(219,223)$. 


\title{
PUCK'S BROOM
}

resonates with Philip Sidney's similar argument in favour of poetic imagination in his Defense of Poesy:

\begin{abstract}
Only the poet, disdaining to be tied to any such subjection, lifted up with the vigour of his own invention, doth grow in effect into another nature, in making things either better than nature bringeth forth or, quite anew, forms such as never were in nature, as the heroes, demigods, cyclopes, chimeras, furies, and such like. So as he goeth hand in hand with nature, not enclosed within the narrow warrant of her gifts but freely ranging only within the zodiac of his own wit. (Alexander 8-9)
\end{abstract}

Theseus, however, displays an ambiguous attitude, revealed in his shifting opinion of the mechanicals' play, ridiculing their clumsiness, as well as initially embracing the honesty of their effort. While we watch the inset play and listen to the increasingly hostile remarks of the courtly audience, we may discover that the function of the inset is interestingly layered. As Madeline Forey notes, the craftsmen's worry over the audience's incapability of distinguishing play from reality reflects the Puritans' fear of fiction being too convincing (326). Yet, the larger play curiously gives much credit to such fears in presenting not only the magic of the fairies transforming the everyday - Demetrius, for example, will continue living as being transformed by the magic flower - but also in accounting for supposed visions, be they theatrical or nocturnal, as truth. Thus, no matter how ridiculous the mechanicals' production may seem, their initial fear, namely the creative potential of fiction, is rather embraced than criticised, and it will be their own hostile audience who will seem ridiculously unimaginative in their lack of appreciation and their unwillingness to participate and play the proper audience of a play which is justly described as "very tragical myrth." Theseus and his court are not endorsing the play of Pyramus and Thisbe the same way we, the audience are invited to take the play by Puck in his closing speeches. Also, the courtly audience seems to be missing more than just the epilogue of the inset play, the bridge that makes sense of the play-world, when they opt for skipping it, since they also miss the fun of playing.

In Puck's penultimate speech, at the end of his "[n] ow the hungry lion roars" (5.1.365) monologue, in which he describes the enchanted hour of the fairies which has come, he tells us that "I am sent with broom before / To sweep the dust behind the door" (5.1.383-384). The significance of Puck's lines is ambiguous. If, while watching the play, the audience thought that they were witnessing a midsummer night's dream, now they are confused: according to Puck, 


\section{ÁGNES MATUSKA \& KAREN KETTNICH}

now is the moment that the fairies, who "following darkness like a dream" (5.1.380) begin to frolic. It seems the dream and the play are just about to begin. This, too, is suggested by the fact that Puck is sent before the group: his task, to sweep behind the door with his broom, seems to prepare the site for the midnight blessing revelry of the fairies. The "hallow'd house" (5.1.382) he is talking about, the site of the feast, would conjure the notion of the site of revelry, a stage of a play, even if he were not on stage, possibly sweeping. The actual stage, curiously, is just about to become empty, now that the fairies - and the actors - are saying their good-byes. So, what exactly is Puck cleaning at the end of the performance and what is he cleaning for? May the answers to these questions illuminate the transition of one playworld to the other, or play-world into reality?

Similar to the confusing status of Puck's cleaning before the arrival of the fairies at the end of the play, his broom has generated some controversy. Puck's attribute of the broom is less ambiguous than its specific use at the end of this play; a tract entitled Robin Goodfellow: His Mad Pranks and Merry Fests published in 1628 actually pictures him with a broom. Several possibilities arise in interpreting the function of Puck's broom and his reference to sweeping. While Wendy Wall argues that Puck "play[s] the role of housewife" (67), ${ }^{6}$ Douglas Bruster links Puck's broom to characters that can be considered as his dramatic ancestors: devils, vices, and tricksters, a group of characters of questionable morality, sometimes comically evil, sometimes playfully subversive, who would establish contact with the audience, and thus would not belong entirely to the mimetic reality of the play but would participate more actively in the audience's reality of watching a play by using direct address or reflecting on the situation of playing, as well as taking active part in creating the play-world. Actors playing Vices would be present on stage in a similar way to Snug's lion: their selves as actors would shine through the character they played. Puck displays several attributes of this tradition of dramatic characters epitomising acting and dramatic disguise, most prominently through his references in the "merry wanderer of the night" (2.1.43) speech, playing all sorts of things from a filly foal through a roasted crab to a three-foot stool. Bruster calls attention to the fact that sweeping was not merely the business of housewives: Puck as a sweeper in a playhouse may stage the normally off-stage duties of the boy actor, whose task, among others, is to clean up the stage

6 Wall's larger claim is that "Dream's pastoral magic both allowed for the gentrification of popular ritual and broadcasted the elite humanist male fantasy of returning to domesticity" - that household sphere which occupied a "vexed but critical place in the cultural imagination" (106). 
(56-57). Anyone who has been to the theatre and remained through the interval or after the show's conclusion will no doubt be aware that stages need sweeping. This, however, does not solve the riddle of why, at the end of the play, Puck still seems to sweep at the beginning of another before the fairies enter. Further evidence, also from Bruster, marks the broom as a ritualistic talisman rather than merely a domestic tool or stage-hand implement. As Bruster points out, Puck is performing a task often seen among the devils of the English Mummers' plays, which, though they were recorded much later, appear to contain elements which go back to the early modern period and before. In several instances, devils sweep at the end of performances, both to collect money from the audience and to clear the stage.

Little Devil Doubt, for example, comes in with a broom and asks the audience threateningly for money:

\author{
In come I, Little Devil Doubt, \\ I you don't give me money \\ I'll sweep you all out
}

or

\author{
Money I want and money I crave; \\ If you don't give us some money \\ I'll sweep you all to the grave. ${ }^{7}$
}

This second example also appears in the Cinderford, Gloucestershire Mummer's Play, perhaps spoken by Beelzebub (Tiddy 162).

In Bruster's words, "[s]uch devils invoke sweeping at the ends of their plays as a ritualistic way of indicating the gathering up of money and the ordering of the performance space" (54). While the examples perfectly illustrate the use of the broom as a tool with which either money is gathered, or the ungrateful audience is swept to the grave, there is no direct and specific reference to cleaning or clearing the stage ritualistically, nor that this gesture marks the end of the game. In a way, though, it does interrupt the flow of the plot by establishing an economic

7 This is cited as it appears in Brody (60). In Tiddy's text of The Mummers' Play, Devil Doubt speaks similar lines to these in the Belfast play, and, though it is unclear who the speaker is, the following lines appear in the Malvern, Worcestershire play: "In comes I little bibble and funny / I am the man to Collect the money / Money I wount money I crave if you dond [sic] give me money / I'll sweep you to the grave" (233). 


\section{ÁGNES MATUSKA \& KAREN KETTNICH}

relationship between the audience and the play, thus ushering back the viewers, if only temporarily, to their everyday reality. With or without broom, collecting money, however, does not necessarily come at the end of the play: one can think of the well-known passage in Mankind when the Vices gather money before the chief attraction, the appearance of Titivillus, the devil (Somerset, 1l. 459-462). It is true, though, that very little remains apart from a Christmas song after Devil Doubt enters in the Derbyshire Mumming Play (John 181-193). Thus, on the one hand, Bruster's reference to "the ordering of the performance space" is rather indirect, while on the other, although Puck's sweeping occurs at the end of A Midsummer Night's Dream, it is clear that he is ordering not after but before: if his sweeping suggests a sweeping connected to ordering a play-space, a stage, it is a ritualistic preparation rather than a closing, which we do not find in the examples of sweeping devils.

The missing link may be offered by Infidelitas, a Vice character who appears in John Bale's Three Laws. After the good characters have all been introduced, at the beginning of the second act, Infidelitas, the playfully corrupt and tricky gamester, enters singing the following: "Brom, brom, brom, brom, brom. Bye brom bye bye. Bromes for shoes and powchrynges, botes and buskyns for newe bromes / Brom, brom, brom" (A6r). Infidelitas enters as broom-seller, a labourer traditionally known to sing and himself a feature of ballads, such as "Hey, Bonny Broom-Man," as were his wares and the plants of which they were fashioned. ${ }^{8}$ Firstly, then, Infidelitas' song about the broom may imply a web of musical connections to popular culture. Furthermore, if the song Infidelitas sings is indeed the one included by Thomas Ravenscroft in his 1611 collection to which it bears a striking similarity, it appears that Infidelitas only knows part of the lyrics and improvises around the portion of the song that is significant to his action in the play, and thus is more obviously connected to the group of semi-dramatic characters, playing their actor selves as well as the dramatic character at the same time, mentioned above. In addition to Infidelitas' scripted improvisations of the ballad's lyrics,

8 For the Broom-man as a singer, see the following verse from Thomas Ravenscroft's A Brief Discourse: "The Broom-man maketh his liuing most sweet, / with carrying of broomes from street to street: /. . Who would desire a pleasanter thing, / then all the day long to doe nothing but sing" (D4r). The tune of "The Bonny Broom" and the Scottish "Broom of Cowdon Knows" were repeatedly recycled into new popular ballads. Wording very similar to Infidelitas' song appears in a song in Whythorne (1571, Ii3v), in Wilson (1584, D4r), as well as Ravenscroft's Melismata (1611), in which it appears: "Brooms for old shoes, Pouchrings, Bootes and Buskins, will yee buy a-ny new Broome?" (Dr). 


\section{PUCK'S BROOM}

as Thora Balslev Blatt points out, though "the lines are evidently meant to be sung, ... Bale leaves it to the actor to supply the missing notes in the staves above the lines" (69).

It is possible to see a connection between his entry crying broom and the typical entry of actors crying "make room" - again in a semi-dramatic fashion. Actors crying "broom" and "room" both imply the idea of clearing the space, and the sound of the two words is so similar, they may be even confused. The Vices in Mankind call for room when they are about to sing their Christmas song: "make room, sirs, for we have to be long" (Lester, 1. 332), "stand aroom, I pray thee" (1. 631), "out of my way sirs" (1. 695), and cry for the audience to "make space" at several points in the play (e.g. 1. 474 and 612). The Enterlude of Youth (1557) features the title character, pushing in, "aback fellows, and give me room / Or I shall make you avoid soon" (Alv), and Cambises" Ambidexter enters telling his audience to "stand away, stand away!" $(\mathrm{A} 4 \mathrm{v})$. As Robert Weimann puts it, "the traditional call for 'room' rang out again and again, but not from the lips of all the actors: those who impersonated the virtuous and pious figures never indulged in this kind of audience address" (102-103).

An initial answer to what these examples of Vices may be sweeping for is literally stage space - room to perform in the crowded inn yard or Tudor hall. But further space must be created in the minds of the audience. Peter Brook famously opens his book on the theatre, The Empty Space, with the statement: "I can take any empty space and call it a bare stage" (9). What Puck seems to be engaged in is turning the space into a stage, as well as the other way round: connecting the world on stage with what is considered to be the off-stage reality of the audience - and he knows he needs their help. As the above examples of the craftsmen's play show, doing it in a way that it is meaningful for the audience does not always happen easily, particularly in case the audience is not ready to lend for play the "empty space" in their minds.

George Chapman hints at this function of the stage broom in The Gentleman Usher when a broom-seller, Pogio, is the first character presented in the second one of the play's two mask-like entertainments. ${ }^{9}$ Pogio lauds the broom in comically hyperbolic terms and finally concludes: "And so we come (gracing your gracious Graces) / To sweepe Care's cobwebs from your cleanly faces” (11. 247-248).

9 This example also may offer Renaissance evidence connecting the broom to Mumming rituals, as the introductory "pedant" figure says his cast, including the "broom-man," present themselves, "without mask or Mumming" (203), perhaps implying that one might naturally connect the broomman to a Mummers' performance. 


\section{ÁGNES MATUSKA \& KAREN KETTNICH}

Part of the work of theatrical entertainment, then, is to negate external concerns. True engagement with performance requires a clearing away of distracting worries, the cobwebs of care. Of course, what is connected to such sweeping is the Classical ideal of purgation and catharsis through theatre - although that sweeping happens at the end of the play rather than at the beginning. As Peter Brook puts it, "the act of theatre is a release. Both laughter and intense feelings clear some debris from the system" (137). But a similar, initial release, a disposition for accepting what is offered by a play, is also required.

Returning to what we have called earlier "the missing link," found in Bale's play, Infidelitas' broom is thus not simply a pedlar's item for sale but indeed the instrument of a "ritualistic ordering of the performance space" on more than one level. Soon after his entry, as it is proper for the legerdemain of creating play-worlds of a Vice, the director of a troupe, he is to conjure Idolatry and Sodomy, mirroring the scene in which God previously summoned his helpers (in the 1538 version of the play). But Infidelitas is sweeping to clean the stage for a broader game, the whole play itself. This notion becomes the more interesting if we bear in mind that, according to a reconstruction of the doubling scheme of the play, Bale, the author played not only the Prolocutor, the prologue to his play, but Infidelitas as well. ${ }^{10}$

Infidelitas ultimately yields his presence in the play to another kind of ritualistic conclusion, as his "brom, brom, brom" gives way to a "credo, credo, credo" - and devilish improvised ballads succumb to ritualised Catholic chant, equally devilish according to Bale's Protestant agenda.

As for Puck's ritualistic sweeping, his ordering of theatrical space makes several promises relating to his broom. Positioned as he is on the threshold of the house and forest, Puck is a bridge between the domestic hearth and all wilderness wolves and hungry lions which might, as in the tale of Pyramus and Thisbe, tragically part the lovers within. As he promises, armed with his broom, "not a mouse / Shall disturb this hallow'd house" (5.1.381-382).

$\mathrm{He}$ is also positioned, as we can glean from his description of the time of night with its screech owls, shrouds, and gaping graves, at Hamlet's "witching time of night" $" 11$ and perhaps it is significant to keep in mind that the association of brooms

10 For the doubling scheme see Happé (156). The idea that Bale played the Vice is also supported by White (2).

11 Hamlet: "Tis now the very witching time of night/ When churchyards yawn, and hell itself breathes out Contagion to this world" (3.2.390-392). 
with witchcraft long predates the days of Harry Potter. According to Reginald Scot, witches were believed to dance with brooms in their rituals (F2v); Thomas Beard's Theatre of God's Judgements from 1597 tells briefly of a Faustian Friar who gives his soul to the devil and flies on a broom $(\mathrm{H} 7 \mathrm{v}-\mathrm{H} 8 \mathrm{r})$; and Henry More's Modest Enquiry Into the Mystery of Iniquity in 1664 equates "witches" with "besom [broom] riders" (P3r). Similarly, Puck, positioned on the threshold between play-creation and play-conclusion, uses the broom not only as a real and metaphorical tool of sweeping away anything that may be threatening to the play to come but also as a means of supernatural transport. Though not sweeping the audience across the boundary of life and death as Little Devil Doubt threatens to sweep unpaying playgoers to the grave, he sweeps the audience across the boundaries of play-world and reality, dream and waking. Interestingly, however, by this point the audience may be unsure about the exact number and the hierarchy of the real and fictional worlds that are inferred here, and through which they may have a free passage, as if flying on a broom. The difference is clear enough between the miraculous reality of the fairy creatures and the Athenians, as well, as well as between the latter and the ridiculed play-world of Pyramus and Thisbe. It is ambiguous, however, where the event (or play?) belongs that Puck prepares with his sweeping - Puck, who is the only go-between connecting not only the different groups of characters within the play, but us, the theatre audience with the world of the play (most obviously through the epilogue). What magic hour is approaching, and how are we to take the fairies who are to arrive and to frolic? Although they had a clear function in regard to the fates of the Athenians, what duty can they have once the plot has ended?

By the end of A Midsummer Night's Dream, Puck has stage-managed the Vicelike antics of the night in the forest - the "accidental" application of the love-juice to Lysander rather than Demetrius and the spontaneous conjuring of the asshead for Titania's induced cravings. The play has been largely his creation, and so is, to read the epilogue, the promise of a future play. Making up with his own epilogue for the epilogue of the craftsmen's play rejected by Theseus, he is offering us two options: we may either imagine that what we saw was not real, just a dream, or endorse the play by participating in it as a willing and accepting, clapping audience - contrary to the ungracious way Theseus and his court behaved in a similar situation. Taking the play as a "mere dream," however, is a tricky and questionable option, since throughout the play, dreams proved to be true, while the dream-world of the fairies seemed to be the most powerful of all. Three times 


\section{ÁGNES MATUSKA \& KAREN KETTNICH}

in the epilogue Puck, remaining alone onstage with his Vice's broom, promises to "mend," "make amends," and "restore amends" with future theatrical fantasies. These lines possibly refer to the audience forgiving the company for the "weak and idle theme" of the play - true, we have to have an empty space for play in our minds to accept the creative potential of fiction that Sidney, too, is talking about, to accept it as a major theme of a whole drama. They can also mean that in case we pardon them, if we accept their questionable state of being as "not real people," be they shadows, fairies, or actors, they will mend not only by ceasing to be questionable entities, but also that they, with their magic powers, will be able to mend whatever is to be set right in our world. The promise of future "mendings" is already at the threshold, waiting for our endorsing clapping hands, since, as we have seen, the plot ends, but Puck, with his broom, has started his preparations for the fairies to enter.

Puck's broom thus, as the broom of a chief playmaker, paradoxically and with a magical sweep, is both ending and beginning the play. He connects not only the appearance of the fairies at the end of the play with the appearance of the actors at the beginning of it but also the idea of the theatre and the "hallow'd house," thus perpetuating the magical, dream-like atmosphere of the play and blurring the boundary between stage magic and the charm of fairies. As the Vice-like director of the game, he is also urging us to "make room," pleading for a playground, as well as an open mental space, in the imagination of the audience, where such plays and dreams can be perceived. At the same time, he is also teaching the early modern audience how to behave, how to take a play, and how to endorse it with their consent. Quite importantly, he is also introducing a relatively new interpretation of the theatre metaphor as well, namely, that life understood as theatre is not necessarily referring to the vanitas-tradition, condemning everything as vain in this unhappy theatre of life, remote from the everlasting divine reality, but rather that theatre, in its shadowy, fictitious state, can present the power that shapes the world. This explicit reference to the role of the audience in participating in the process of the construction of social reality through the fiction of theatrical play is very much in line with early modern ideas about readership, the role of the audience in theatre, as well as the formation of a public discourse. ${ }^{12}$ Thus, apart from the fact that Puck's broom reminds us on several levels of earlier cultural and theatrical traditions, such as magic, stage devils, and trickster Vices, and their characteristically close

12 On the idea that contemporary audiences, rather than remaining passive consumers, took an active part in producing and shaping the meaning of plays they watched, see Whitney. 


\section{PUCK'S BROOM}

relation to members of the public, it also includes an appeal for the future as well. It refers to the play that is just about to begin, as if in a theatrum mundi, starting when the audience leaves the theatre and enters the world where it remains in their power to use the same broom for purposes they think fit. This is why the craftsmen's playwithin-a-play is made ridiculous to the extent any theatre can be, since it enacts an insufficient knowledge of the social code defining a play's function. ${ }^{13}$ The function of the play, ultimately, will be realised by its audience. Their fear, just like the fear of Puritans, was not unfounded: the audience may indeed embrace the creative potential of fiction. Just like the way the broom can be read as a tool marking the continuity between the fairy world and the real one, so, too, the version of the theatre metaphor the whole play suggests is the continuity between stage and audience reality, as well as the reality of theatres at the liminal territories of the city and the rest of London. Shakespeare's play is part of a contemporary social discourse, it positions itself both as an audience and active performer within it and celebrates, interestingly, not only playing but what it presents: the type of reality infused with playing. The really interesting question perhaps targets the decision of the audience, the drive that leads them - once they embrace their power in inaugurating worldviews with their applause at the end of plays - to support a new version of the play metaphor and, thus, a new perspective of their own reality.

\section{Works Gited}

Alexander, Gavin, ed. Sidney's "The Defense of Poesy" and Selected Renaissance Literary Criticism. London: Penguin Books, 2004.

Bale, John. A Comedy Concerning Three Lawes, of Nature, Moses, and Christ [. . .]. 1548. Early English Books Online. Web. 22 Jan 2019.

Barish, Jonas. The Antitheatrical Prejudice. Berkeley: University of California Press, 1981. Bate, Jonathan. Shakespeare and Ovid. Oxford: Oxford University Press, 1993.

Beard, Thomas. The Theatre of God's Judgments: Or, a Collection of Histories Out of Sacred, Ecclesiasticall, and Profane Authors Concerning the Admirable Judgements of God [. . .]. 1597. Early English Books Online. Web. 22 Jan 2019.

Belsey, Catherine. A Future for Criticism. Hoboken: Wiley-Blackwell, 2011.

13 Bate reads this inset play as Shakespeare's parody of his own habit of literary borrowing and adapting (41). 


\section{ÁGNES MATUSKA \& KAREN KETTNICH}

Blatt, Thora Balslev. The Plays of John Bale: A Study of Ideas, Technique, and Style. Copenhagen: G. E. C. Gad Publishers, 1968.

Brody, Alan. The English Mummers and Their Plays: Traces of Ancient History. London: Routledge and Kegan Paul, 1969.

Brook, Peter. The Empty Space. New York: Touchstone, 1968.

Bruster, Douglas. Shakespeare and the Question of Culture: Early Modern Literature and the Cultural Turn. New York: Palgrave, 2003.

Calderwood, James L. Shakespearean Metadrama. Minneapolis: University of Minnesota Press, 1971.

Chapman, George. The Gentleman Usher. Ed. Smith, John Hazel. Lincoln: University of Nebraska Press, 1970.

Christian, Lynda. Theatrum Mundi: The History of an Idea. New York and London: Garland Publishing, 1987.

Cope, Jackson I. The Theatre and the Dream: From Metaphor to Form in Renaissance Drama. Baltimore: The Johns Hopkins University Press, 1973.

The Enterlude of Youth. 1565. Early English Books Online. Web. 22 Jan 2019.

Forey, Madeline. "'Bless thee, Bottom, bless thee! Thou Art Translated!’: Ovid, Golding, and 'A Midsummer Night's Dream."' The Modern Language Review 93.2 (1998): 321-329.

Happé, Peter, ed. Fohn Bale. Complete Plays I-II. Cambridge: D. S. Brewer, 1985.

Hornby, Richard. Drama, Metadrama and Perception. London and Toronto: Associated University Presses, 1986.

John, Gwen. "The Derbyshire Mumming Play of St. George and the Dragon; Or, as It Is Sometimes Called, the Pace Egg." Folklore 32.3 (Sep 1921): 181-193.

Kastan, David Scott, Richard Proudfoot, and Ann Thompson, eds. Arden Shakespeare Complete Works. New York: Bloomsbury, 1998.

Lester, G. A., ed. Three Late Medieval Morality Plays. New York: Norton, 1981.

Matuska, Ágnes. "Masking Players, Painted Sepulchres and Double Dealing Ambidexters' on Duty: Anti-Theatrical Tracts on Audience Involvement and the Transformative Power of Plays." Yearbook of the Spanish and Portuguese Society for English Renaissance Studies (2008): 45-59.

More, Henry. A Modest Enquiry Into the Mystery of Iniquity. 1664. Early English Books Online. Web. 22 Jan 2019.

Mullaney, Steven. The Place of the Stage: License, Play, and Power in Renaissance England. Chicago: University of Chicago Press, 1988. 


\section{PUCK'S BROOM}

Preston, Thomas. [. . .] Cambises, King of Percia [. . .]. 1570. Early English Books Online. Web. 22 Jan 2019.

Ravenscroft, Thomas. Melismata. 1611. Early English Books Online. Web. 22 Jan 2019. -. A Brief Discourse [. . .] of Charactering the Degrees [. . .] in Measurable Music. 1614. Early English Books Online. Web. 22 Jan 2019.

Righter, Anne. Shakespeare and the Idea of Play. Harmondsworth: Penguin, 1967.

Scot, Reginald. The Discovery of Witchcraft. 1584. Early English Books Online. Web. 22 Jan 2019.

Somerset, J. A. B., ed. “Mankind.” In Four Tudor Interludes. London: Atholone Press, 1974. Tiddy, R. J. E. The Mummers' Play. Oxford: Clarendon Press, 1923.

Wall, Wendy. "Why Does Puck Sweep?" Shakespeare Quarterly 52.1 (Jan 2001): 67-106. Weimann, Robert. Shakespeare and the Popular Tradition in the Theatre: Studies in the

Social Dimension of Dramatic Form and Function. Baltimore: Johns Hopkins University Press, 1978.

White, Paul Whitfield. Theatre and Reformation. Protestantism, Patronage, and Playing in Tudor England. Cambridge: Cambridge University Press, 1993.

Whitney, Charles. Early Responses to Renaissance Drama. Cambridge: Cambridge University Press, 2006.

Whythorne, Thomas. Triplex of Songs for Three, Four, and Five Voices. 1571. Early English Books Online. Web. 22 Jan 2019.

Wilson, Robert. The Three Ladies of London. 1584. Early English Books Online. Web. 22 Jan 2019.

\section{Contributor Details}

Ágnes Matuska is associate professor at the English Department, University of Szeged, Hungary. Her main field of research is English renaissance drama, particularly issues of the changes in the logic and ontology of theatrical representation at the Early Modern. In her book entitled The Vice-Device: Iago and Lear's Fool as Figures of Representational Crisis (Szeged: JatePress, 2011), she suggests a re-evaluation of the Vice character of morality plays. Currently, she is working on projects including the diverse traditions of metadrama and the theatrum mundi metaphor in the Renaissance, as well as the ways our understandings of the topos influence not only our readings of plays but contemporary performances building on this tradition. She is the recipient of Folger Shakespeare Fellowships (2007 and 2013) and 


\section{ÁGNES MATUSKA \& KAREN KETTNICH}

a Fulbright Research Fellowship (2011), and editor of the visual culture and theory journal Apertúra.

Karen Kettnich is a lecturer in English at Clemson University, where she teaches courses in World Literature. She is also Managing Editor of The Library Quarterly and The International Fournal of Information, Diversity, and Inclusion. Her work has been published in Early Theatre, Shakespeare (The Journal of the British Shakespeare Association), and in the volumes Ki Merre Tart?: Shakespeare-Szegeden, 2007-2011 (Szeged: JatePress, 2013) and The Age of Nashe: Print Culture, Elizabethan London, and Definitions of Authorship (Ashgate, 2013). 